\title{
Perinatal death associated with ET, IVP and cloning in cattle Mette Schmidt
}

\author{
Address: Associate Professor, DVM, PhD, Veterinary Reproduction and Obstetrics, Faculty of Life Sciences, University of Copenhagen, Denmark \\ Email: Mette Schmidt - mhs@life.ku.dk
}

from Perinatal Death In Domestic Animals: The 20th Symposium of the Nordic Committee for Veterinary Scientific Cooperation (NKVet) Reykjavik, Iceland. 26-27 April 2007

Published: 12 December 2007

Acta Veterinaria Scandinavica 2007, 49(SuppI I):SI3 doi:I0.II86/I75I-0I47-49-SI-SI3

This abstract is available from: http://www.actavetscand.com/content/49/SI/SI3

(c) 2007 Schmidt; licensee BioMed Central Ltd.

During the last decades, assisted reproduction has found wide application in cattle, but with increasing manipulation of the embryos the mortality of the fetus and offspring have been shown to increase. Manipulation of early embryos induces subtle modifications of the developmental capacity resulting in changes of the maternalembryonic interaction and the fetal adaptation and in abnormalities, which become apparent during pregnancy and delivery.

By definition, assisted reproductive techniques in the bovine include ET, MOET, IVP and cloning [1-3]:

Embryo transfer (ET) is the process of transferring embryos from donors to recipients which are synchronised to the appropriate day after heat. Embryos for transfer can either be developed in vivo (MOET) or in vitro (IVF).

MOET (multiple ovulations and embryo transfer) is the technology which is used worldwide to produce $80 \%$ of embryos for commercial purposes. The embryos are produced by superovulation of the donor cow with eCG or $\mathrm{FSH}$, which are administered in the mid-luteal phase of the estrus cycle of the donor over a 3 to 4 days period and are combined with induced luteolysis and estrus. The donor is inseminated during estrus, and 7 days later the uterus is flushed to recover on average four to six transferable good quality embryos. Half of the commercially produced embryos are transferred fresh and the other half is frozen for later transfer.
IVP is the in vitro production of embryos where immature oocytes are recovered from the ovaries in the live cow by transvaginal aspiration, so called OPU (ovum pick-up) using an ultrasound scanner equipped with a transducer and a guided needle. Alternatively, when the female parental origin is not required to be known, the oocytes are collected from slaughterhouse ovaries. Several culture protocols can be used to mature, fertilize and culture the oocytes for about one week to blastocyst stage which is suitable for transfer or freezing. IVP embryos contribute with $20 \%$ to the commercially transferred embryos, which are mainly transferred freshly. Pregnancy rates are generally about $40-45 \%$ after fresh transfers, but become more variable amongst different laboratories with frozen embryos.

Cloning is the process of fusing a donor cell (often a differentiated cell from an adult) with an oocyte, from which the nucleus, containing the DNA, has been removed. Under this process, the genome of the donor cells is transferred to the recipient oocyte and reprogrammed to the status of an undifferentiated cell, which can undergo embryonic development. Thus, genetically identical offspring of already existing individuals can be created. Cells harvested from preimplantation embryos, fetuses or adult animals - typically fibroblasts, cumulus and granulosa cells or mammary epithelial cells (Dolly) - can be used to produce these clones. The efficiency is still low and only about $5 \%$ of the cloned bovine blastocysts transferred to recipients survive to term. So far, 12 different animal species have been cloned, but cloning has not yet become commercially important. This technology may, however 
find its main application in the production of transgenic animal models for biomedical industry.

\section{Mortality during pregnancy}

In vitro produced and cloned embryos are acutely sensitive to environmental conditions, but adverse repercussions of such sensitivities may not be manifest, until much later in development and the long-term consequences may have different times of sensitivity within the developing embryo. Conceptuses, fetuses and offspring resulting from those embryos can differ in their viability, morphology and physiology compared with in vivo controls [4-8]. A better understanding of these mechanisms will not only facilitate the refinement of IVP and cloning systems, but may also improve our management of pregnant animals.

After transfer of cloned embryos, $60 \%$ or more of the pregnancies are lost in the first trimester of pregnancy. This is followed by a small but constant loss of the remaining pregnancies up to the 8 months, which is an unusual pattern in the extent and timing of pregnancy loss. These pregnancy losses can be attributed to a defective placental function, as demonstrated by an initial reduction of cotyledon development. Later in the pregnancy the abortions are associated with placenta hypertrophy, enlarged cotyledons and thickening of the umbilical cord [9-11].

Under certain culture conditions (coculture and use of serum-supplemented medium) IVP embryos and cloned embryos may develop large offspring syndrome (LOS), in which late fetal losses are associated with excess fetal size, abnormal placental development and vasculature (i.e. hydroallantois, enlarged edematous placentomes in reduced numbers), extremely large umbilical veins and arteries and abnormal, asynchronous growth of organs with musculoskeletal deformities. Overall, there is a higher incidence of LOS in clones compared to in vitro derived embryos, and especially in clones produced from somatic cells compared with clones produced from embryonic cells $[7,10,12-14]$.

Chromosomal abnormalities are a well-known cause of pregnancy failure and chromosomally abnormal cells are commonly found in IVP or cloned embryos. However, the frequency reported varies with the method of embryo production. The most frequently observed deviation from the diploid karyotype is mixoploidy resulting from aberrant cell division causing polyploidy in a variable proportion of an embryo's cells $[15,16]$.

\section{Mortality at delivery}

Most of the born calves derived from in vitro produced embryos appear normal, but a number of deviations have been reported that together have been termed as LOS.
These include weak labor in the recipients, extended gestation, dystocia, increased incidence of hydrallantois, congenital malformations, increased birth weight and higher incidence of perinatal mortality. Live offspring occasionally exhibit heart insufficiency and respiratory distress with pulmonary hypertension. A wide range of other illnesses have been reported in clones, including infections, somatic overgrowth and omphalocele. Apparently normal clones show physiologic particularities such as alterations in temperature regulation and increased abdominal fat and leptin concentrations. Some of these calves require considerable intensive care to support their initial survival $[10,11,17-23]$.

One possible approach to reduce the perinatal morbidity/ mortality of offspring derived from assisted reproductive technologies is to provide the appropriate assistance during delivery. A number of procedures such as inducing parturition have been developed for this purpose; however, these protocols did not significantly reduce parturient and neonatal disorders following transfer of IVP or NT embryos [24]. Even when the adverse effects of dystocia are prevented by cesarean section, prenatal problems persist and evidence suggests that these are consequences of energy metabolism defects resulting from placental insufficiency. The majority of parturient complications may be explained by an inadequate signaling between mother and fetus associated with deficiencies in the establishment of placental vasculature.

Until an age of 5 months, the mortality of cloned calves is up to $40 \%$ [25] and between weaning and 4 years of age, the annual mortality rate in cattle cloned from somatic cells is approximately $10 \%$. The LOS is the consequences of abnormal programming occurring during early embryonic development, which becomes manifest throughout gestation, the neonatal period and during adulthood in the cloned animal, but it does not appear to be transmitted to subsequent offspring following sexual reproduction $[26,27]$.

The increased perinatal mortality in calves born after assisted reproduction involves ethical and economic concerns which have to be attended solved if the methods are to be used for commercial purposes such as breeding and production of transgenic animals for pharmaceutical production.

\section{References}

I. Forsberg EJ, Strelchenko NS, Augenstein ML, Betthauser JM, Childs LA, Eilertsen KJ, Enos JM, Forsythe TM, Golueke PJ, Koppang RW, Lange G, Lesmeister TL, Mallon KS, Mell GD, Misica PM, Pace MM, Pfister-Genskow M, Voelker GR, Watt SR, Bishop MD: Production of cloned cattle from in vitro systems. Biol Reprod 2002, 67:327-333.

2. Galli C, Duchi R, Crotti G, Turini P, Ponderato N, Colleoni S, Lagutina I, Lazzari G: Production and quality of bovine oocytes and embryos. Vet Res Commun 2004, 28(Suppl I): I 2 | - I 26. 
3. Lagutina I, Lazzari G, Duchi R, Turini P, Tessaro I, Brunetti D, Colleoni S, Crotti G, Galli C: Comparative aspects of somatic cell nuclear transfer with conventional and zona-free method in cattle, horse, pig and sheep. Theriogenology 2007, 67:90-98.

4. Lazzari G, Wrenzycki C, Herrmann D, Duchi R, Kruip T, Niemann H, Galli C: Cellular and molecular deviations in bovine in vitroproduced embryos are related to the large offspring syndrome. Biol Reprod 2002, 67:767-775.

5. Mcevoy TG, Ashworth CJ, Rooke JA, Sinclair KD: Consequences of manipulating gametes and embryos of ruminant species. Reprod Suppl 2003, 61:167-182.

6. Bertolini M, Moyer AL, Mason JB, Batchelder CA, Hoffert KA, Bertolini LR, Carneiro GF, Cargill SL, Famula TR, Calvert CC, Sainz RD, Anderson GB: Evidence of increased substrate availability to in vitro-derived bovine foetuses and association with accelerated conceptus growth. Reproduction 2004, I 28:34I-354.

7. Farin PW, Piedrahita JA, Farin CE: Errors in development of fetuses and placentas from in vitro-produced bovine embryos. Theriogenology 2006, 65:178-191.

8. Thompson JG, Mitchell M, Kind K: Embryo culture and long-term consequences. Reprod Fertil Dev 2007, 19:43-52.

9. Heyman Y, Chavatte-Palmer P, LeBourhis D, Camous S, Vignon X, Renard JP: Frequency and occurrence of late-gestation losses from cattle cloned embryos. Biol Reprod 2002, 66:6-13.

10. Chavatte-Palmer P, Heyman Y, Richard C, Monget P, LeBourhis D, Kann G, Chilliard Y, Vignon X, Renard JP: Clinical, hormonal, and hematologic characteristics of bovine calves derived from nuclei from somatic cells. Biol Reprod 2002, 66:1596-1603.

II. Galli C, Duchi R, Crotti G, Turini P, Ponderato N, Colleoni S, Lagutina I, Lazzari G: Bovine embryo technologies. Theriogenology 2003, 59:599-616

12. Young $L E$, Sinclair KD, Wilmut $I:$ Large offspring syndrome in cattle and sheep. Rev Reprod 1998, 3:155-163.

13. Bertolini M, Mason JB, Beam SW, Carneiro GF, Sween ML, Kominek DJ, Moyer AL, Famula TR, Sainz RD, Anderson GB: Morphology and morphometry of in vivo- and in vitro-produced bovine concepti from early pregnancy to term and association with high birth weights. Theriogenology 2002, 58:973-994.

14. Bertolini M, Anderson GB: The placenta as a contributor to production of large calves. Theriogenology 2002, 57:181-187.

15. Viuff D, Palsgaard A, Rickords L, Lawson LG, Greve T, Schmidt M, Avery B, Hyttel P, Thomsen PD: Bovine embryos contain a higher proportion of polyploid cells in the trophectoderm than in the embryonic disc. Mol Reprod Dev 2002, 62:483-488.

16. Slimane-Bureau WC, King WA: Chromosomal abnormalities: a potential quality issue for cloned cattle embryos. Cloning Stem Cells 2002, 4:319-329.

17. Kruip TAM, denDaas JHG: In vitro produced and cloned embryos: Effects on pregnancy, parturition and offspring. Theriogenology 1997, 47:43-52.

18. Jacobsen H, Schmidt M, Holm P, Sangild PT, Vajta G, Greve T, Callesen $\mathrm{H}$ : Body dimensions and birth and organ weights of calves derived from in vitro produced embryos cultured with or without serum and oviduct epithelium cells. Theriogenology 2000, 53:1761-1769.

19. van Wagtendonk-de Leeuw AM, Mullaart E, de Roos AP, Merton JS, den Daas JH, Kemp B, de Ruigh L: Effects of different reproduction techniques: AI MOET or IVP, on health and welfare of bovine offspring. Theriogenology 2000, 53:575-597.

20. Sangild PT, Schmidt M, Jacobsen H, Fowden AL, Forhead A, Avery B, Greve T: Blood chemistry, nutrient metabolism, and organ weights in fetal and newborn calves derived from in vitroproduced bovine embryos. Biol Reprod 2000, 62: I 495-I 504.

21. Gibbons J, Arat S, Rzucidlo J, Miyoshi K, Waltenburg R, Respess D, Venable A, Stice S: Enhanced survivability of cloned calves derived from roscovitine-treated adult somatic cells. Biol Reprod 2002, 66:895-900.

22. Pace MM, Augenstein ML, Betthauser JM, Childs LA, Eilertsen KJ, Enos JM, Forsberg EJ, Golueke PJ, Graber DF, Kemper JC, Koppang RW, Lange G, Lesmeister TL, Mallon KS, Mell GD, Misica PM, Pfister-Genskow M, Strelchenko NS, Voelker GR, Watt SR, Bishop MD: Ontogeny of cloned cattle to lactation. Biol Reprod 2002, 67:334-339.

23. Forsyth JT, Wells DN: Health and neonatal care of bovine clones. Methods Mol Biol 2006, 348:9I-108.
24. Ptak G, Clinton M, Tischner M, Barboni B, Mattioli M, Loi P: Improving delivery and offspring viability of in vitro-produced and cloned sheep embryos. Biol Reprod 2002, 67:1719-1725.

25. Panarace M, Aguero JI, Garrote M, Jauregui G, Segovia A, Cane L, Gutierrez J, Marfil M, Rigali F, Pugliese M, Young S, Lagioia J, Garnil C, Forte Pontes JE, Ereno Junio JC, Mower S, Medina M: How healthy are clones and their progeny: 5 years of field experience. Theriogenology 2007, 67:142-151.

26. Wells DN: Animal cloning: problems and prospects. Rev Sci Tech 2005, 24:25I-264.

27. Wells DN, Forsyth JT, McMillan V, Oback B: The health of somatic cell cloned cattle and their offspring. Cloning Stem Cells 2004, 6:101-110.
Publish with Bio Med Central and every scientist can read your work free of charge

"BioMed Central will be the most significant development for disseminating the results of biomedical research in our lifetime. "

Sir Paul Nurse, Cancer Research UK

Your research papers will be:

- available free of charge to the entire biomedical community

- peer reviewed and published immediately upon acceptance

- cited in PubMed and archived on PubMed Central

- yours - you keep the copyright

Submit your manuscript here:

http://www.biomedcentral.com/info/publishing_adv.asp
BioMedcentral 